\title{
Technological Valorization of Algerian Dates Downgraded from Deglet Nour Variety to Semi-Candied Dates in Dates Syrup
}

\author{
Férial Aziza Benyahia-Krid ${ }^{1 * \#, ~ E l h e y f a ~ K h e m i s s a t ~}{ }^{2 *}$, 0. Aissaoui Zitoun1, Kaouther Djafri2 ${ }^{2}$ \\ Meriem Bergouia'², Batoul Meghzili' ${ }^{1}$, Lamia El-Mechta ${ }^{1}$
}

${ }^{1}$ Laboratoire de Génie Agro-Alimentaire (GENIAAL), Institut de la Nutrition, de l'Alimentation et des Technologies Agro-Alimentaires (I.N.A.T.A-A.), Université Frères Mentouri Constantine 1, Constantine, Algérie

${ }^{2}$ Institut National de la Recherche Agronomique d'Algérie INRAA, station expérimentale de Sidi Mehdi, Touggourt, Algérie

Email: "benyahia.ferial.aziza@umc.edu.dz, "ferialaziza@yahoo.fr

How to cite this paper: Benyahia-Krid, F. A., Khemissat, E., Aissaoui Zitoun, O., Djafri, K., Bergouia, M., Meghzili, B. and El-Mechta, L. (2021) Technological Valorization of Algerian Dates Downgraded from Deglet Nour Variety to Semi-Candied Dates in Dates Syrup. Food and Nutrition Sciences, 12, 627-642.

https://doi.org/10.4236/fns.2021.126047

Received: May 6, 2021

Accepted: June 26, 2021

Published: June 29, 2021

Copyright $\odot 2021$ by author(s) and Scientific Research Publishing Inc. This work is licensed under the Creative Commons Attribution International License (CC BY 4.0).

http://creativecommons.org/licenses/by/4.0/

(c) (i) Open Access

\begin{abstract}
The objective of this study is the valorization of downgraded dates from a high Algerian date variety Deglet Nour, locally called "h'chef". The work starts with the implementation of a food formulation of semi-candied dates in syrup extracted from dates. This formulation was based on dehydration-impregnation by immersion (D.I.I.). The downgraded dates were cleaned, cut, blanched, and then immersed in date syrups with increasing differential concentrations in Brix degrees: $65^{\circ}, 70^{\circ}$ and $75^{\circ}$. The chosen date/syrup immersion ratio is $1: 2(\mathrm{w} / \mathrm{w})$. The obtained semi-candied dates were the subject of physicochemical and sensory analyses. The characterization of the downgraded dates before immersion showed high sugar content with a rate 52.67 $\mathrm{g} \% \mathrm{~g}$ of dry matter and low water content (14\%) which favors their use in semi-candied products. The physico-chemical analyses results of the three semi-candied dates products show an increase in their final sugar content, i.e. from $53.55 \%$ to $60.78 \%$ and in ashes between 1.76 p.cent and 1.94 p.cent. On the other hand, sensory analysis results confirm that the semi-candied dates with a syrup of $75^{\circ}$ Brix present the most appreciated and preferable organoleptic characteristics than the other variables. Finally, following appertisation, the stability test reveals good microbiological quality $\left(100^{\circ} \mathrm{C}\right.$ for 20 minutes) of the three (3) semi-candied formulations of dates. Thus, the valorization of the "h'chef" as sorting gap Deglet Nour date allowed its transformation into semi-candied dates, stable, appreciable on the organoleptic side. This new formulation could constitute a value-added product if eventually manufactured on an industrial scale, mainly in southern Algeria.
\end{abstract}




\section{Keywords}

Phoenix dactylifera L., Downgraded Dates, Food Formulation, Osmotic Dehydration, Stability Test

\section{Introduction}

The dates in the date palm (Phoenix dactylifera L.) provide resources whose importance does not need to be demonstrated. As a symbol of oasis agriculture, the date palm is the creator of a center of life and the source of inestimable values: economic, religious, moral and ecological [1].

According to the FAO (2017), the world production of dates is estimated at 8.5 million tonnes in 2014.

With more than 17 million palm trees and 800 varieties, Algeria occupies an important place among producing and exporting countries of dates all over the world.

In addition, thanks to Deglet Nour variety, Algeria has ranked the first in terms of quality. As with regard to export earnings, dates are the number one agricultural product exported by the country. In 2017, Algeria exported nearly 46,600 tonnes of dates with $\$ 52$ million [2]. In recent years, the sector has witnessed a certain dynamism which has resulted in a significant increase in production. In Algeria, the production of dates is estimated at 789.35 tons of which a more or less important part (100,000 tons on average) is less appreciated in the market.

The sorting gap date is a prime substrate for the development of high added value substances. In this context, we will cite the main products made with. Thus, sorting gap dates must, rich in fermentable sugars, (approximately $75 \%$ ), can be transformed by biotechnological processes into bioethanol, which constitutes an interesting solution as from an economic point of view. Indeed, it can replace light petroleum as a biofuel or at least allow the gasoline blending from $5 \%$ to $10 \%$ of ethanol [3] [4].

On the other hand, the same must mentioned above can be used for the production of vinegar by a double simultaneous alcoholic and acetic fermentation by Saccaromyces uvarum or Saccaromyces cerevisiae. Its color varies depending on the variety of dates used [5] [6].

Also, scraps and date stones can be used as livestock feed. Date stone flour can be incorporated at a rate of $10 \%$ in the feed of chickens without negatively influencing their performance [7].

For date syrups, they are obtained by diffusing the constituents of the washed, pitted and crushed date slices using hot water as a solvent at $65^{\circ} \mathrm{C}$. Then the product is pressed, then purified, clarified, filtered and finally concentrated in vacuo. The Brix degree date syrup obtained is between 70 and 75 [8].

The production involves common dates and sorting differences from $\mathrm{Deg}$ let-Nour variety, commonly called "h'chef" [9]. In fact, Deglet-Nour represents more than $50 \%$ of the national date palm orchard [10] [11]. The latter matures in stages on the same bunch so that when harvested, one will obtain ripe dates, 
completely immature dates (Blah), and shriveled and desiccated dates "h'chef". The last category can reach $30 \%$ of total palm production depending on the climatic conditions of the year, irrigation, fertilization, as well as care of palms and bunches [12]. In order to find them a more profitable outlet, we have considered it useful to promote this category of downgraded date through its technological transformation into candied fruits. Actually, confectionery is a technological process based on osmotic dehydration (DO). This energy-saving technique is likely to extend the period of availability of food products and give them new and appreciated sensory properties. In addition, it offers actors in the agro-food sector the opportunity to sell their products at better prices and in different forms throughout the year [13].

The objective of the present work is to contribute to the enhancement of "h'chef" sorting gap of Deglet Nour variety by transforming it into semi-candied dates in date syrup. This would allow the diversification of using date syrup to produce novel, highly consumable, and easily marketable products.

\section{Material and Methods}

\subsection{Plant Material}

\subsubsection{Dates}

The plant material consists of Deglet Nour waste. It is made from shriveled dates that have dried out before maturity, commonly called "h'chef". The dates used in this study come from palm groves in the region of Oued-Righ (Touggourt Wilaya, Southern Algeria). Figure 1 shows a sample of "h'chef" of Deglet Nour used in the preparation of the product.

\subsubsection{Dates Syrup}

Date syrups with different total solid substance (TSS) contents of $65 \%-70 \%$ and $75 \%$ were purchased from the local market of Touggourt (Wilaya of Ouargla) in glass jars. The Brix degree of the syrups was checked before use.

\subsection{Methods}

\subsubsection{Preparation of the Samples}

Preparation steps of the semi-candied dates are mentioned in Figure 2. The dates were picked homogeneously at the same stage of maturity; they were

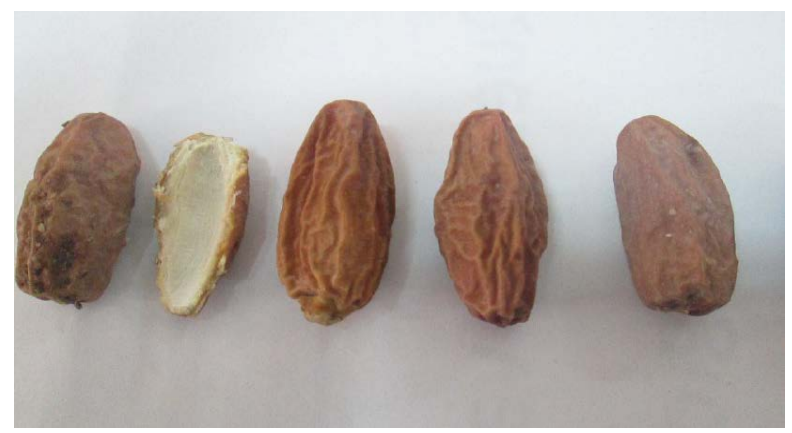

Figure 1. Deglet Nour "h'chef" date scraps variety. 


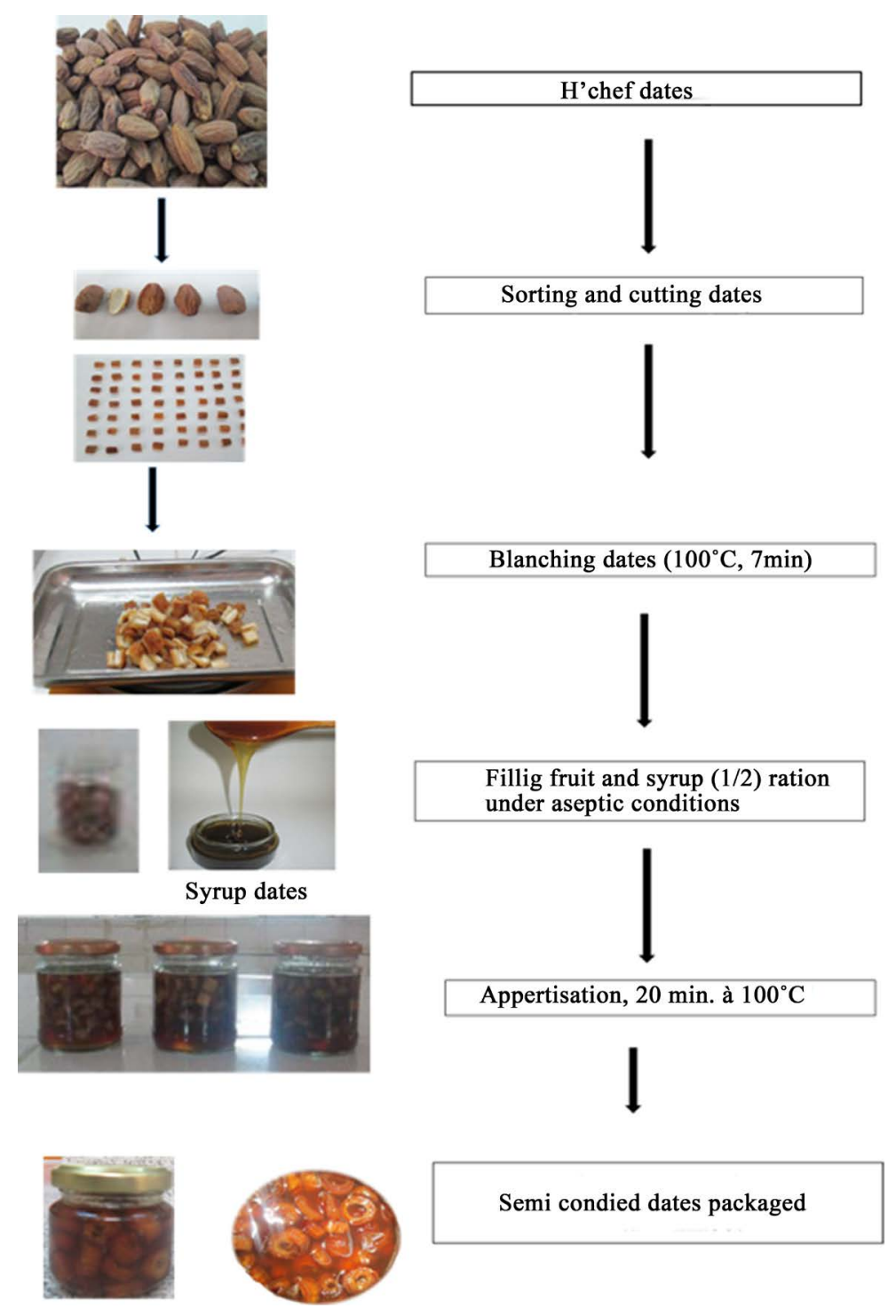

Figure 2. Semi-candied dates preparation steps.

washed, pitted and cut into small pieces in cubic forms of $1 \mathrm{~cm}^{3}$. The cubic geometry has the advantage of having a specific surface area perfectly known to homogenize the mass transfer during osmotic dehydration [14]. They were, then, bleached in a solution of $1 \%$ citric acid with the ration: fruit/water of: $1 / 2$ at $100^{\circ} \mathrm{C}$ for 7 minutes. The blanching was followed by immediate cooling in order not to affect the nutritional and organoleptic value of the dates. After that, everything (content and container) underwent a sterilization treatment.

\subsubsection{Confection}

Confection was done by osmotic dehydration, also called dehydration impregnation by immersion [15] [16]. This operation was carried out in a concentrated solution of date syrup. The pieces of previously blanched dates were placed in sterile jars; then, the date syrup at different degrees ${ }^{\circ}$ Brix $\left(60^{\circ}, 70^{\circ}\right.$ and $\left.75^{\circ}\right)$ was added. Osmotic dehydration was performed at room temperature. The fruit/syrup ra- 
tio used for these experiments was 1:2.

The three formulations developed for semi-candied dates based on date syrup were:

- semi-candied A: date syrup of $65^{\circ}$ Brix + "h'chef" dates from Deglet Nour.

- semi-candied B: date syrup of $70^{\circ}$ Brix + "h'chef" dates from Deglet Nour.

- semi-candied C: date syrup of $75^{\circ}$ Brix + "h'chef" dates from Deglet Nour.

\subsection{Biochemical Characterization of the Raw Material and Date Syrup}

The physico-chemical analyzes of dates and date syrup focused on the determination of $\mathrm{pH}$, and the content of: water, total ash, Brix, total sugars, acidity, fibers, as well as the determination of the density of syrups.

\subsection{1. $\mathrm{pH}$}

It was determined by direct reading on a previously calibrated JANWAY type $\mathrm{pH}$ meter as described in NF V-05-108, 1970 [17].

\subsubsection{Water Content}

This was determined by desiccating $10 \mathrm{~g}$ of dates in a porcelain dish and then drying them in an oven at a temperature of $103^{\circ} \mathrm{C} \pm 2{ }^{\circ} \mathrm{C}$ until a constant weight was obtained as described in (A.O.A.C, 1970) [18].

\section{Expression of results}

Water content is determined according to the following formula

$$
H \%=\frac{\left(M_{1}-M_{2}\right)}{\left(M_{1}-M_{0}\right)} \times 100
$$

where:

$H \%$ : water or humidity content,

$M_{0}$ : mass (g) of the empty capsule,

$M_{1}$ : mass of the capsule + fresh material before drying $(\mathrm{g})$,

$M_{2}$ : mass of the capsule mass of the capsule + residual material after drying (g).

\subsubsection{Total Ash Content}

Determined by incineration of $3 \mathrm{~g}$ of dates in a muffle furnace at a temperature of $550^{\circ} \mathrm{C}$ until complete combustion of the organic matter and obtaining a whitish ash as described in NFV-05-113, 1972, [17].

Expression of results

The ash content expressed in $\%$ is given by the following formula:

$$
\text { Ashes } \%=\frac{\left(M_{2}-M_{1}\right) \times 100}{M_{0}}
$$

where:

$M_{0}$ : mass of the test sample (g).

$M_{1}$ : mass of crucible.

$M_{2}$ : mass of crucible + ash. 


\subsubsection{Brix (\%)}

It expresses the percentage of soluble solids incorporated in a sample (aqueous solution). The content of soluble solids (TSS) is the total of all solids dissolved in water, including sugars, alcohol, salt, protein, acids, etc. [18].

The Brix of the samples is determined with a portable refractometer. The reading was done by placing a drop of syrup on the instrument's hinge plate, facing the light. The Brix value was noted. It was necessary to clean the refractometer with distilled water after each reading to ensure that no particles remain on the plate.

\subsubsection{Total Sugars (Reducing Sugars and Sucrose)}

The sugars were determined by the Bertrand method, reported by [19]. The principle of this method involves making an excess of cuproalkaline liquor act under well-defined conditions. Then, the cuprous oxygen was separated and was treated with a sulfuric ferric sulphate liquor. In this case, only the reducing sugars were assayed. To assay the total sugars, an acid hydrolysis was first carried out in order to free the aldehyde or ketone functions. In this way, the sucrose was transformed into reducing sugars.

$$
\text { Saccharose } \%=(\text { sucres totaux }- \text { sucres réucteurs }) \times 0.95
$$

\subsubsection{Titratable Acidity}

It is determined by the neutralization of citric acid with a $0.1 \mathrm{~N} \mathrm{NaOH}$ solution in the presence of a colored indicator (phenolphthalein) as described in NF V 05-101, 1974 [17]. The titratable acidity of the sample was calculated according to the following formula:

$$
\text { Acidité titrable } \%=V \times 0.064
$$

$V$ : the volume in $\mathrm{ml}$ of $\mathrm{NaOH}$ used.

\subsubsection{Fibers}

They are determined by the method of Weende which is summarized in two acid hydrolyses and another alkaline separated by filtration and rinsing with hot water as described in NF V03-40, 1993, [17]. The dry residue constitutes the crude cellulose which includes true cellulose, hemicellulose and lignin.

$$
\text { fibre } \%=\frac{\left(M_{1}-M_{2}\right) \times 100}{P}
$$

where:

$M_{1}$ : Mass of crucible + dry residue.

$M_{2}$ : crucible mass.

$P$ : mass of the test sample.

\subsubsection{Density}

It was determined by a direct reading on an automatic refractometer of the REICHERT AR6 type. The average density of a syrup depends on its concentration. The latter is inversely proportional to the ambient temperature [20]. 


\subsubsection{Microbiological and Physicochemical Stability Test}

The stability test for canned foods made from acidic plant foods with a $\mathrm{pH}$ greater than 4.5 is determined according to the Algerian standard J.O.R.A. $\mathrm{n}^{\circ}$ 035 [21] and the French standard NFV 08-401 (reference method); NF V 08-408 (routine method) [22].

\subsection{Sensory Analyses}

The samples consist of categories A, B and C with three different formulations. Semi-candied A: date syrup of $65^{\circ}$ Brix + "h'chef" dates, semi-candied B: date syrup of $70^{\circ}$ Brix + "h'chef" dates and semi-candied C: date syrup of $75^{\circ}$ Brix + "h'chef" dates. These samples were presented to thirty (30) subjects anonymously with a simple three-digit coding. Four criteria were evaluated: texture, color, taste and odor. The average value of these sensory properties was evaluated as an overall acceptability. The samples were assessed and compared on a 9-point hedonic scale, from the point "not pleasant" to "very pleasant" [23].

\subsection{Statistical Analysis}

Parameter values were expressed as mean \pm standard deviation. The statistical analysis was performed using XLSTAT 2014. The One-Way ANOVA test was used to assess the significance of differences between the values of the means at $p$ $<0.05 \%$ level. For the hedonic test, the Friedman test was used to assess significance.

\section{Results and Discussion}

\subsection{Physicochemical Characterization of "h'chef" Date Pulp from Deglet-Nour}

Physicochemical characteristics of dates are demonstrated in Table 1.

The chemical composition data presented in Table 1 show that the "h'chef" of Deglet Nour variety of dates contains a high amount of sugars, low water content, and moderate ash and fiber levels.

Moisture content of the " $h$ 'chef" date is $14 \%$. This value is slightly higher than

Table 1. Biochemical composition of date pulp h'chef.

\begin{tabular}{cc}
\hline Parameters & Results \\
\hline Water content (\%) & $14 \pm 0.11$ \\
Brix degree & $25 \pm 1.63$ \\
pH & $5.9 \pm 0.1$ \\
total sugars (\%) where: & $45.30 \pm 1.83$ \\
Reducing sugars (\%) & $18.2 \pm 0.07$ \\
Saccharose (\%) & $25.74 \pm 1.21$ \\
Acidity (\%) & $1.31 \pm 0.05$ \\
Total ash (\%) & $2.14 \pm 0.07$ \\
Fibers (\%) & $3.4 \pm 0.05$ \\
\hline
\end{tabular}


that cited by [24] which gives a content of $11.98 \%$ for the dry variety 'Mech Deglet, and the one given by [25] for the "h'chef" category of Adar region (which is around 9.02\%). However, it is clear from the data obtained that moisture content of the analyzed dates is very close to the recorded average of $15 \%$ for the semi-dry Saudi "Reziz" date varieties [26].

According to [27], the required moisture content for the marketing of dates is $26 \%$ for common date varieties. This humidity level allows dates to be preserved for a long period of storage at room temperature without the risk of deterioration.

\subsection{1. pH Level}

The $\mathrm{pH}$ value of dates of category "h'chef" is 5.9. This result is slightly higher than that given by [24] which is 5.52 for Mech deglet variety. Compared to foreign varieties, this result is comparable to the $\mathrm{pH}$ of the two Emirati varieties: Gash Gaafar and Bushibal (dry dates) which are 5.3 and 5.4, respectively [28]. The category of "h'chef" dates is of acceptable taste quality. According to [29], dates with a $\mathrm{pH}$ of less than 5.5 are acid dates and are of poor taste quality.

\subsubsection{Sugars}

The level of total sugars is $45.30 \%$ of the fresh weight of the dates, or $52.67 \%$ of dry matter (DM), of which $18.20 \%$ is reducing sugars. These values show the richness of the date in sugars. The major fraction of sugars is composed essentially of sucrose with a content of $25.74 \%$ of fresh matter (MF). Our results are superior to those obtained by [25] which give a value of $48.49 \%$ (DM) of total sugars for the category of "h'chef". This difference can be affected by various factors such as variety, growing conditions, maturity, season, geographic origin, fertilization, soil type, storage conditions, sun exposure time and harvest period [30].

\subsection{Physicochemical Characteristics of Syrup}

The results of physicochemical analyses of syrup are summarized in Table 2.

Regarding the physicochemical characteristics of the three date syrups shown in Table 2, the syrup with the highest Brix degree of 75 is the one with the highest sugars content and density and the lowest water content. Compared to other characteristics of other syrups, the highest humidity (43.48\%), is that of the syrup of Brix degree lowest 65\%. These results are close to those obtained by [31]. for the syrup of the Ghars variety ( $60^{\circ}$ Brix) which is of the order of $41.75 \%$ and are superior to those obtained by [32] which presents values oscillating between $20 \%$ and $22 \%$ for syrup with a degree of Brix between $72 \%$ and $74 \%$. In fact, water content also depends on condensation. The purpose of this operation is to lower water activity of the syrups and, thus, to facilitate their preservation. The density of date syrup is very high thanks to the level of soluble solids that exist in this product. This character allows their storage for a long time [33]. The density of the three syrups prepared varies between 1.084 and 1.13. These results cor- 
respond to those obtained by [32]. and are included in the interval [1 - 1.5]. Under the effect of concentration, the syrups obtained are richer in sugars, mineral substances and bioactive substances, which are high compared to those of raw materials [34]. Total sugars content fluctuates between $60 \%$ and $74 \%$. These values are comparable to those reported by [32]. For three varieties: Ghars, Deglet Nour and deglet Baida which vary from $70 \%$ to $73.68 \%$. The sucrose content for the "h'chef" category is close to that reported by [31] for the dry variety Mech-deglet which is $25.10 \%$.

The three syrups represent an important source of mineral elements varying between $1.90 \%$ and $2.4 \%$ (DM). These results are lower than those obtained by [25] for syrup of h'chef variety which is of the order of $5.7 \%$ and is slightly higher than the syrup of Mech-deglet variety of the order of 1.64\% (DM). This difference can be explained by the difference in ash content of the raw material.

\subsection{Physicochemical Composition of Formulated Semi-Candied Dates}

The physicochemical characteristics of the semi-candied dates are presented in Table 3.

Table 2. Physicochemical characteristics of dates syrups.

\begin{tabular}{|c|c|c|c|c|}
\hline \multicolumn{2}{|c|}{ Paramètres } & \multicolumn{3}{|c|}{ Sirops } \\
\hline \multicolumn{2}{|c|}{ Brix degree } & $65 \%$ & $70 \%$ & $75 \%$ \\
\hline \multicolumn{2}{|c|}{$\mathrm{pH}$} & 5.80 & 5.75 & 5.70 \\
\hline \multicolumn{2}{|c|}{ Humidity (\%) } & 43.48 & 38 & 32.68 \\
\hline \multicolumn{2}{|c|}{ Acidity degree } & 1.92 & 1.84 & 1.79 \\
\hline \multicolumn{2}{|c|}{ ash (\%) (Matièresèche) } & 2.4 & 2.1 & 1.9 \\
\hline \multicolumn{2}{|c|}{ Density } & 1.084 & 1.109 & 1.137 \\
\hline & totals & 60 & 64 & 74 \\
\hline \multirow{2}{*}{$\begin{array}{c}\text { Sugars }(\%) \\
\text { (fresh material where: }\end{array}$} & Reducing & 41 & 50 & 53 \\
\hline & Saccharose & 18 & 13 & 19 \\
\hline
\end{tabular}

Table 3. Physicochemical characteristics of semi candied dates.

\begin{tabular}{cccc}
\hline & Semi-candied dates A & Semi-candied dates B & Semi-candied dates C \\
\hline Brix degree & $44.16 \pm 2.35 \mathrm{a}$ & $47.5 \pm 3.81 \mathrm{a}$ & $50.58 \pm 3.23 \mathrm{a}$ \\
Humidity (\%) & $37.60 \pm 0.09 \mathrm{a}$ & $36.26 \pm 0.14 \mathrm{a}$ & $33.48 \pm 0.16 \mathrm{a}$ \\
pH & $5.30 \pm 0.015 \mathrm{a}$ & $5.35 \pm 0.023 \mathrm{a}$ & $5.26 \pm 0.025 \mathrm{a}$ \\
Total sugar (\%) & $53.55 \pm 0.4 \mathrm{a}$ & $57.49 \pm 1.06 \mathrm{a}$ & $60.78 \pm 0.23 \mathrm{a}$ \\
Reducing sugar (\%) & $25.68 \pm 4.45$ & $28.98 \pm 3.62$ & $30.15 \pm 3.85$ \\
Saccharose (\%) & $26.30 \pm 5.2$ & $26.48 \pm 4.54$ & $28.92 \pm 4.24$ \\
ash (\%) & $1.76 \pm 0.09$ & $1.88 \pm 0.10$ & $1.94 \pm .19$ \\
\hline
\end{tabular}

(a) indicates the significance between the values $(\mathrm{p}<0.05)$. 
The results of the physicochemical characteristics of semi-candied dates illustrate a significant difference between the three samples. The Brix of semi-candied dates increases significantly with total soluble solids content of date syrup. The sugars content is between $53.55 \%$ and $60.86 \%$ (MF), which is the highest value recorded for semi-candied $\mathrm{C}$ date sweetened with $75^{\circ}$ Brix date syrup. We recorded a decrease in the sugars content in all formulations $\mathrm{A}, \mathrm{B}$ and $\mathrm{C}$ in comparison to syrup preparation. This would be explained as the combination of the fruit in syrup.

The highest water content of $36.7 \%$ is recorded for dates immersed in the least concentrated syrup of $65^{\circ}$ Brix; and the lowest of $31.51 \%$ for dates immersed in the most concentrated syrup of 75 . This value is reflected by the difference in solute concentration between the to-be-treated product (date) and the solution, the engine of mass transfer in osmotic dehydration (DO) (syrup). Water loss is greater when the difference in solute concentration between the dates and the syrup is initially high [35] [36].

Globally, the opposing transfers of water and solute (sugars) lead to improved texture and a slight change in taste. As a result, date syrup rich in invert sugars (fructose, glucose) gives a mellow appearance [16] [37].

\subsection{Microbiological Stability Test}

The physicochemical characteristics of the semi-candied dates are presented in Table 4.

The variation between the $\mathrm{pH}$ of the samples stored at room temperature $37^{\circ}$ C. and $55^{\circ} \mathrm{c}$ in all cases remains below $0.5 \mathrm{pH}$ units. According to the two standards of [21], and [22] a conserve is considered stable if the $\mathrm{pH}$ measurement of the steamed samples and the $\mathrm{pH}$ of the control should not exceed $0.5 \mathrm{pH}$ unit under room temperature during the chosen periods. Therefore, the effectiveness of appertization is proven. A variation in $\mathrm{pH}$ reflects microbial activity, equivalent with that under sterilization.

\subsection{Sensory Characteristics}

The statistical results of the hedonic test for each descriptor for the three elaborated products are shown in Table 5 and Figure 3.

According to the results of statistical analysis, the viscosity, color and taste of the three semi-candied preparations show a significant difference $(p=0.01$ for the viscosity attribute; $\mathrm{p}=0.007$ for the color attribute; and $\mathrm{p}=0.03$ for the taste attribute). The semi-candied dates B (date syrup of $70^{\circ}$ Brix + dates " $h$ 'chef") and the semi-candied dates $C$ (date syrup of $75^{\circ}$ Brix + dates " $h$ 'chef") are indeed distinguished from semi-candied A dates $\left(60^{\circ}\right.$ Brix date syrup + "h'chef" dates) by their typical viscosity and distinguished color. For taste, sample $\mathrm{C}$ is the sweetest, followed by sample B. As an explanation, the sugar content is highest in semi-candied date $\mathrm{C}$, which is sweetened by date syrup $\left(75^{\circ}\right.$ Brix). This gives a high viscosity and a dark color compared to the other semi-candied dates. 
Table 4. Stability test of semi candied dates, $\mathrm{pH}$ variation depending on temperature.

\begin{tabular}{cccc}
\hline $\mathrm{pH}$ & Semi-candied dates A & Semi-candied dates B & Semi-candied dates C \\
\hline $\mathrm{pH} 130^{\circ} \mathrm{C}$ (21 days) & $5.1 \pm 0.84$ & $5.10 \pm 0.007$ & $5.16 \pm 0.10$ \\
$\mathrm{pH} 237^{\circ} \mathrm{C}$ (7 days $)$ & $5.24 \pm 0.04$ & $5.23 \pm 0.04$ & $5.24 \pm 0.02$ \\
$\mathrm{pH} 355^{\circ} \mathrm{C}$ (7 days $)$ & $5.05 \pm 0.07$ & $5.06 \pm 0.14$ & $5.10 \pm 0.14$ \\
\hline
\end{tabular}

Table 5. Analysis of the differences by Friedman's test between the three semi-candied dates with a level of significance of $5 \%$.

\begin{tabular}{|c|c|c|c|c|c|}
\hline Character & Sample & Mean & SD & $P_{\text {_ value }}$ & Groups \\
\hline \multirow{3}{*}{$\begin{array}{c}\text { General } \\
\text { appreciation }\end{array}$} & A & 5.307 & 2.175 & \multirow{3}{*}{0.3229} & A \\
\hline & B & 6.384 & 1.325 & & A \\
\hline & $\mathrm{C}$ & 6.538 & 2.145 & & A \\
\hline \multirow{3}{*}{ Aspect } & A & 5.538 & 2.331 & \multirow{3}{*}{0.2008} & A \\
\hline & B & 6.461 & 1.853 & & A \\
\hline & $\mathrm{C}$ & 7.077 & 1.891 & & A \\
\hline \multirow{3}{*}{ Viscosity } & A & 4.250 & 1.908 & \multirow{3}{*}{0.0113} & A \\
\hline & B & 6.250 & 1.035 & & $\mathrm{AB}$ \\
\hline & $\mathrm{C}$ & 7.125 & 1.553 & & B \\
\hline \multirow{3}{*}{ Mellow date } & A & 5.000 & 1.915 & \multirow{3}{*}{0.1913} & A \\
\hline & B & 6.000 & 2.160 & & A \\
\hline & $\mathrm{C}$ & 6.428 & 1.718 & & A \\
\hline \multirow{3}{*}{ Attraction } & A & 5.375 & 2.133 & \multirow{3}{*}{0.0224} & A \\
\hline & B & 5.500 & 2.070 & & A \\
\hline & $\mathrm{C}$ & 7.250 & 1.389 & & A \\
\hline \multirow{3}{*}{ Typical color } & A & 5.769 & 1.481 & \multirow{3}{*}{0.0007} & A \\
\hline & B & 6.692 & 1.377 & & A \\
\hline & $\mathrm{C}$ & 8.154 & 0.555 & & B \\
\hline \multirow{3}{*}{ Typical smell } & A & 6.692 & 1.931 & \multirow{3}{*}{0.5945} & A \\
\hline & B & 7.230 & 1.012 & & A \\
\hline & $\mathrm{C}$ & 7.153 & 1.143 & & A \\
\hline \multirow{3}{*}{ Sweet taste } & A & 6.615 & 1.709 & \multirow{3}{*}{0.0302} & A \\
\hline & B & 7.461 & 1.330 & & $\mathrm{AB}$ \\
\hline & $\mathrm{C}$ & 7.769 & 1.481 & & B \\
\hline \multirow{3}{*}{ Acidity } & A & 1.615 & 0.869 & \multirow{3}{*}{0.1266} & A \\
\hline & B & 2.077 & 1.891 & & A \\
\hline & $\mathrm{C}$ & 1.538 & 1.391 & & A \\
\hline \multirow{3}{*}{ Aftertaste } & A & 1.154 & 0.375 & \multirow{3}{*}{0.2231} & A \\
\hline & B & 1.077 & 0.277 & & A \\
\hline & $\mathrm{C}$ & 1.308 & 0.630 & & A \\
\hline
\end{tabular}


Continued

\begin{tabular}{cccccc}
\hline & A & 1.000 & 0.000 & & $\mathrm{~A}$ \\
Caramel taste & B & 1.250 & 0.866 & 0.3679 & $\mathrm{~A}$ \\
& C & 1.250 & 0.866 & & $\mathrm{~A}$ \\
\hline Product & $\mathrm{A}$ & 3.769 & 2.315 & & $\mathrm{~A}$ \\
purchase & $\mathrm{B}$ & 4.307 & 1.974 & 0.0608 & $\mathrm{~A}$ \\
& $\mathrm{C}$ & 5.461 & 1.450 & & $\mathrm{~A}$ \\
\hline
\end{tabular}

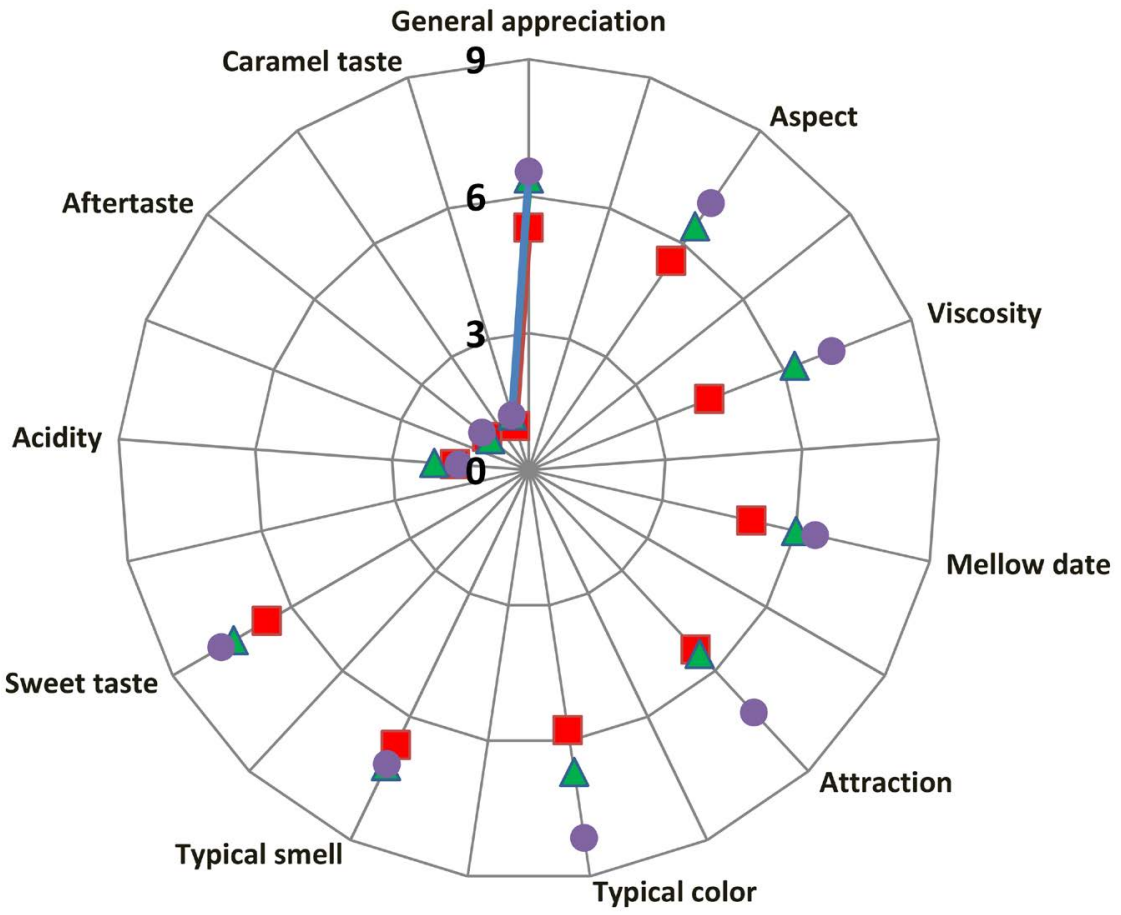

Figure 3. Test hedonic results of the three semi-candied dates prepared A, B and C: Legend: A (־) (semi candied date A: 65 degree Brix date syrup + "h'chef" of DegletNour dates), B ( $\Delta$ ) (semi candied date B: 70 degree Brix date syrup + "h'chef" of DegletNour dates), C ( ): (semi candied date C: 75 degree Brix date syrup + "h'chef" of DegletNour dates).

In parallel, the other descriptors (attributes) (Table 5) do not reveal a significant difference $(p>0.05)$ between the samples. However, all the subjects agree on the absence of acidity, aftertaste and caramel taste in the analysed samples.

\section{Conclusions}

The obtained results of this study show that the "h'chef" date category has a high dry matter content of approximately $86 \%$, and that it is rich in sugar $(45.30 \%$ MF) and ash (2.14\%). The analysis of syrups with different concentrations of $65^{\circ}, 70^{\circ}$ and $75^{\circ}$ degree Brix reveals their high levels of mineral salts and sugar. In fact, the more concentrated the syrup, the higher the sugar content. The sugar content obtained for the $65^{\circ}$ Brix syrup is $60 \%$; that of the $70^{\circ}$ Brix syrup is $64 \%$; and that of the $75^{\circ}$ Brix syrup is $74 \%$. 
The physico-chemical analyses of the three produced semi-candied dates show their high content in sugar (between $53.55 \%$ and $60.78 \%$ ) and ash (between $1.76 \%$ and $1.94 \%)$.

The stability test demonstrates good microbiological quality of the semi-candied dates following their compliance with Algerian and French standards.

On the other hand, the sensory analysis shows that the semi-candied dates with $75^{\circ}$ Brix syrup are those with the most appreciated and preferable organoleptic characteristics.

To remind, the aim of the present work is twofold: to enhance the phoenicultural heritage of Southern Algeria, and to develop a food formulation with an increased value "h'chef" which is a sorting gap of the variety of Deglet Nour. This waste constitutes a local agricultural product suitable for being transformed, by the osmotic dehydration process, into semi-candied dates in date syrup. This process makes it possible to improve the texture of shriveled and dried "h'chef" dates and to increase their nutritional value. As a result, a new generation of products with a considerable socio-economic impact can be brought to the national market and, probably, to the international market. This would make it possible to create jobs and make strategic substances in high demands available to manufacturers and, therefore, to consumers.

\section{Conflicts of Interest}

The author declares no conflicts of interest regarding the publication of this paper.

\section{References}

[1] Toutain, G. (1996) Rapport de synthèse de l'atelier "Techniques culturales du palmier dattier. In: Ferry, M. and Greiner, D., Eds., Le palmier dattier dans l'agriculture d'oasis des pays méditerranéen, Options méditerranéennes, Ed (IAM), Zaragoza, 201-205. https://om.ciheam.org/om/pdf/a28/96605890

[2] Bessaoud, O., Pellissier, J.-P., Rolland, J.-P. and Khechimi, W. (2019) Rapport de synthèse sur l'agriculture en Algérie. [Rapport de recherche] CIHEAM-IAMM, Montpellier, 82.

[3] Kaidi, F. and Touzi, A. (2001) Production de Bioalcool à Partir des Déchets de Dattes 2001. In: Review Energy Renewable: Production et Valorisation-Biomasse, 75-78. http://www.cder.edu.dz/download/bio 11.pdf

[4] Boulal, A., Benali, B., Moulai, M. and Touzi, A. (2010) Transformation des déchets de dattes de la région d'Adrar en bioéthanol. Revue des Energies Renouvelables, 13, 455-463. https://www.researchgate.net/publication/335056036

[5] Benamara, S., Gougam, H., Amellal, H., Djouab, A., Benahmed, A. and Noui, Y. (2008) Some Technologic Properties of Common Date (Phoenix dactiliféra L.) Fruits. American Journal of Food Technology, 3, 79-88. https://doi.org/10.3923/ajft.2008.79.88

[6] Bouaziz, S., Oueld, E.L. and Hadj, M.D. (2021) Contribution à l'étude des caractéristiques physico-chimiques et biochimiques de quelques types de vinaigres traditionnels de dattes obtenues à partir de quelques variétés de la région de 
OUARGLA. Annals of Science and Technology, 2, 7.

https://journals.univ-ouargla.dz/index.php/AST/article/view/1272

[7] Gualtieri, M. and Rapaccini, S. (1990) Date Stones in Broiler's Feeding. Tropicultura, 8, 165-168.

https://www.researchgate.net/publication/284779432 Date stones in broiler\%27s feeding

[8] Mimouni, Y. and Siboukeur, O.E.K. (2011) Etude des propriétés nutritives et diététiques des sirops de dattes extraits par diffusion, en comparaison avec les sirops à haute teneur en fructose (isoglucoses), issues de l'industrie de l'amidon. Annual Review of Food Science and Technology, 3, 1-11. http://scholar.google.com/citations? user=jr0C9DkAAAAJ\&hl=fr

[9] El-Hadi, D., Korteby, S. and Chibi, S. (2016) Production du bioéthanol à partir de rebut de deux variétés de dattes (deglet-nour et hamraya). Revue Agrobiologia, 6, 111-120.

http://agrobiologia.net/online/production-du-bioethanol-a-partir-de-rebut-de-deux -varietes-de-dattes-deglet-nour-et-hamraya/

[10] Brac de la Perrière, R. and Benkhalifa, A. (1982) Rapport des missions de prospection sur l'Ouest du Sahara Algérien, Alger, URZA, (Doc ronéo, pag,mult).

[11] Hannachi, S., Khitri, D., Benkhalifa, A. and Brac de la Perriere, R.A. (1998) Inventaire variétal de la palmeraie algérienne. Ed. Anep, Rouïba, 225.

[12] Djerbi, M. (1994) Précis phoeniciculture. FAO, Rome, 192 p. https://core.ac.uk/download/pdf/35401679.pdf

[13] Bchir, B., Besbes, S., Giet, J.-M., Attia, H. and Bleckerm C. (2011) Synthèse des connaissances sur la déshydratation osmotique. Biotechnology, Agronomy and Society and Environment, 15, 129-142.

https://www.researchgate.net/publication/50235211

[14] Castello, M., Igual, M., Fito, P. and Chiralt, A. (2009) Influence of Osmotic Dehydration on Texture, Respiration and Microbial Stability of Apple Slices (Var, Granny Smith). Journal of Food Engineering, 91, 1-9. https://doi.org/10.1016/j.jfoodeng.2008.07.025

[15] Maltini, E. and Torreggiani, D. (2003) La déshydratation osmotique et les produits de semi-confisage, Le sucre et la conservation des produits à base de fruits. 32-38. https://docplayer.fr/35301521

[16] Corrêa, J., Pereira, L., Vieira, G. and Hubinger, M. (2010) Mass Transfer Kinetics of Pulsed Vacuum Osmotic Dehydration of Guavas. Journal of Food Engineering, 96, 498-504. https://doi.org/10.1016/j.jfoodeng.2009.08.032 https://www.researchgate.net/publication/222123032

[17] Recueil des normes françaises (A.F.N.O.R.) (1986) Produits dérivés des fruits et légumes, jus de fruits. 2nd edition, AFNOR, Paris, France, $343 \mathrm{p}$. https://bdsp-ehesp.inist.fr/vibad/index.php?action=getRecordDetail\&idt=14383

[18] Association of Official Analytical Chemists (1970) Official Methods of Analysis. 11th Edition, Association of Official Analytical Chemists, Washington DC.

[19] Audigié, C.I., Figarella, J. and Zonszani, F. (1984) Manipulation of biochemical analyzies. Ed. Doin editors, Paris, 211 p.

[20] Guerin, B., Gauthier, A. and Orthieb, J. (1982) Série de synthèse bibliographique: Les sirops (Saccharose, glucose, fructose et autres édulcorants: Valeur technologique et utilization. No. 18, Ed. Apria, Paris, 123 p.

[21] J.O.R.A. (Journal Officiel de la République Algérienne) (1998) Journal Officiel de la 
République Algérienne, arrêté interministériel du 24 janvier 1998 relatif aux spécifications microbiologiques de certaines denrées alimentaires.

[22] AFNOR (Association Française de Normalisation) (1997) Microbiologie des aliments. Contrôle de la stabilité des produits appertisés et assimilés. Méthode de référence, méthode AFNOR, 1997-10, NF V 08-401, p. 1-12 et méthode de routine NF V 08-408.

https://www.boutique.afnor.org/norme/nf-v08-408/microbiologie-des-aliments-con trole-de-la-stabilite-des-produits-appertises-et-assimiles-methode-de-routine/articl e/757270/fa045341

[23] Watts, B.M., Ylimaki, G.L., Jeffery, L.E. and Elias, L.G. (1991) Méthodes de base pour l'évaluation sensorielle des aliments. International Development Research Centre, Ottawa, 159 p.

https://idl-bncidrc.dspacedirect.org/bitstream/handle/10625/3774/IDL-3774.pdf?se quence $=1$

[24] Noui, Y. (2016) Fabrication et caractérisation des produits alimentaires élaborés à base de dattes (Phoenix dactylifera L,) Thèse de Doctorat en Sciences (Technologie Alimentaire), université Batna, Batna, 59-61. http://theses.univ-batna.dz/

[25] Boutouta, A. and Amroune, O. (2016) Possibilité de fabrication d'un jus naturel diététique à base de sirop de datte et jus de grenade et détermination de sa qualité thèse présentée en vue d'obtention du diplôme master université de Tébessa.

http://dspace.univ-eloued.dz/

[26] El-Sharnouby, G.A., Aleid, S.M. and Al-Otaibi, M.M. (2014) Liquid Sugar Extraction from Date Palm (Phoenix dactylifera L.) Fruits. Journal of Food Process Technology, 5, Article No. 402. https://doi.org/10.4172/2157-7110.1000402

[27] FAO/WHO (1985) Codex Alimentarius. Normes codex pour les dattes CODEX STAN 143-1985, 1-5.

https://bdsp-ehesp.inist.fr/vibad/index.php?action=getRecordDetail\&idt=14383

[28] Al-Hooti, S., Sidku, S. and Qabazard, H. (1997) Physicochemical Characteristics of Five Date Fruit Cultivars Grown in the United Arab Emirates. Plant Foods for Hitman Nutrition, 50, 101-113. https://doi.org/10.1007/BF02436030

[29] Acourene, S., Djafri, K., Benchabane, A., Tama, M. and Taleb, B. (2014). Dates Quality Assessment of the Main Date Palm Cultivars Grown in Algeria. Annual Research \& Review in Biology, 4, 487-499. https://doi.org/10.9734/ARRB/2014/5009 https://www.journalarrb.com/index.php/ARRB/article/view/25003/46769

[30] Al-Farsi, M., Alasalvar, C., Morris, A., Baron, M. and Shanidi, F. (2005) Compositional and Sensory Characteristics of Three Native Sun-Dried Date (Phoenix dactylifera L.) Varieties Grown in Oman. Journal of Agricultural and Food Chemistry, 50, 7586-7591. https://www.academia.edu/1087753/ https://doi.org/10.1021/jf050578y

[31] Benahmed, D.A. (2012) Analyse des aptitudes technologiques de poudres de dattes (Phoenix dactelifera. L) améliorées par la spiruline. Etude des propriétés rhéologiques, nutritionnelles et antibactériennes. Thèse Doctorat, Université M'hamed Bougara-Boumerdes, Boumerdès.

http://dlibrary.univ-boumerdes.dz:8080/jspui/bitstream/123456789

[32] Mimouni, Y. (2015) Développement de produits diététiques hypoglycémiants à base de dattes molles variété “Ghars", la plus répandue dans la cuvette de Ouargla. Doctorat, université Kasdi Merbah, Ouargla. https://bu.univouargla.dz/Theses\%20DOCTORAT/Mimouni-Yamina-Doctorat.pdf

[33] Abdelfattah, A.C. (1990) La date et le palmier dattier. Ed Dar El-Talae, Caire. 
[34] Abbès, F., Bouaziz, M., Blecker, C., Masmoudi, M., Attia, H. and Besbes, S. (2011) Date Syrup: Effect of Hydrolytic Enzymes (Pectinase/Cellulase) on Physicochemical Characteristics, Sensory and Functional Properties. LWT-Food Science and Technology, 44, 1827-1S34. https://doi.org/10.1016/j.lwt.2011.03.020

[35] Raoult-Wack, A.L. and Guilbert, S. (1990) La Déshydratation Osmotique ou procédé de Déshydratation-Imprégnation par Immersion dans des solutions concentrées. Les Cahiers de L'ENSBANA “L'eau dans les procédés de transformation et de conservation des aliments, 7, 171-192.

[36] Raoult-Wack, A.L. (1994) Recent Advances in the Osmotic Dehydration of Foods. Trends in Food Science \& Technology, 5, 255-260. https://doi.org/10.1016/0924-2244(94)90018-3

[37] Torreggiani, D. and Bertolo, G. (2001) Osmotic Pre-Treatments in Fruit Processing: Chemical, Physical and Structural Effects. Journal of Food Engineering, 49, 247-253. https://doi.org/10.1016/S0260-8774(00)00210-7 